\title{
Sediment biogeochemistry along an oyster aquaculture chronosequence
}

\author{
Nicholas E. Ray ${ }^{1, *}$, Alia N. Al-Haj ${ }^{2}$, Robinson W. Fulweiler ${ }^{1,2}$ \\ ${ }^{1}$ Boston University, Department of Biology, 5 Cummington Mall, Boston, MA 02215, USA \\ ${ }^{2}$ Boston University, Department of Earth and Environment, 685 Commonwealth Ave, Boston, MA 02215, USA
}

\begin{abstract}
Oyster aquaculture is expanding globally, and there has been a recent research surge examining how oyster farms alter coastal ecosystems. Yet, until now, the role of time in these studies has largely been missing. Here we used an in situ chronosequence approach to determine how the presence of oyster aquaculture (Crassostrea virginica) altered sediment nitrogen (N), oxygen $\left(\mathrm{O}_{2}\right)$, and phosphorus (P) cycling. Overall we found that the sum of nitrogen fluxes increased significantly following addition of aquaculture, and switched from net $\mathrm{N}$ consumption (i.e. net nitrogen fixation: $-14.41 \mu \mathrm{mol} \mathrm{N} \mathrm{m}{ }^{-2} \mathrm{~h}^{-1}$ ) to production (i.e. net denitrification: $553.57 \mu \mathrm{mol} \mathrm{N} \mathrm{m} \mathrm{N} \mathrm{h}^{-1}$ ). Ammonium $\left(\mathrm{NH}_{4}{ }^{+}\right)$fluxes did not differ between bare sediment and oyster aquaculture. Additionally, both the magnitude of $\mathrm{N}_{2}$ and $\mathrm{NH}_{4}{ }^{+}$fluxes oscillated on an annual scale of aquaculture age, but not predictably so. We observed significantly more variance $\left(\sigma^{2}\right)$ in dinitrogen and $\mathrm{NH}_{4}{ }^{+}$fluxes in sediments beneath aquaculture, indicating increased non-linearity. $\mathrm{O}_{2}$ fluxes increased from Years 4 to 6 , before returning to baseline conditions. There were no differences in sediment $\mathrm{P}$ cycling. This study demonstrates that sediment biogeochemical processes can become non-linear under the pressure of oyster aquaculture, and this non-linearity likely has important implications for ecosystem function.
\end{abstract}

KEY WORDS: Denitrification · Dissolved inorganic nitrogen · Dissolved inorganic phosphorus · $\mathrm{N}: \mathrm{P} \cdot$ Nitrous oxide $\cdot$ Oysters $\cdot$ Aquaculture

\section{INTRODUCTION}

Long-term pressures on ecosystems such as nutrient loading, higher temperatures, and reduced light availability can lead to major shifts in biodiversity, productivity, and energy flow (Ryther \& Dunstan 1971, Scheffer et al. 2001, Beisner et al. 2003, Marsland et al. 2019). As an example, long-term nutrient enrichment in aquatic ecosystems can drive a system formerly characterized by submerged, rooted plants to one dominated by floating plants (Valiela et al. 1992, Scheffer et al. 2003), although as the pressure is released following reductions in nutrient load, the system can return to its previous condition (Lefcheck et al. 2018). In a shift like this, where the system re-

${ }^{*}$ Corresponding author: nray@bu.edu sponds uniformly over time under pressure, the community characteristics change, but variance along the trajectory of change can remain homogeneous, indicating rapid restructuring of processes within the system. Pressures may also lead to the development of non-linear, or even oscillatory, patterns in community characteristics and structure as feedback loops and interactions between guilds and trophic groups in the system develop and change (Benincà et al. 2008, Penn et al. 2019). Non-linear patterns may be indicated by greater variance within the system over time, and potential changes in mean community characteristics or function for brief time periods. In other cases, the system may be resistant to the pressure, and no change in mean or variance will occur.

(C) The authors 2020. Open Access under Creative Commons by Attribution Licence. Use, distribution and reproduction are unrestricted. Authors and original publication must be credited. 
A recent pressure in some coastal systems is the re-establishment of oyster populations through restoration projects and development of aquaculture. Oysters apply pressure to the benthos by moving significant quantities of material suspended in the water column to sediments below, and the oysters themselves excrete dissolved nutrients (Fig. 1). There is much interest in how oysters may change sediment biogeochemical processes, yet recent studies yield conflicting results, possibly due to only collecting measurements in a relatively short period of time (i.e. 1 or 2 yr), and not considering how sediment biogeochemistry may respond over time. If we consider oysters as a pressure on sediment processes, and investigate how this pressure regulates sediment biogeochemical processes over time, we may improve our understanding of the impact of oysters on benthic processes and provide some explanation for the disparities between studies. In this study, we tested how the length of time oyster aquaculture has been in place influences sediment biogeochemical processes. We then determined if the observed patterns best describe a sediment system that changes rapidly and restructures under pressure, one in which feedback loops and non-linearity develop, or a system resistant to the pressure of oyster aquaculture.

In coastal ecosystems, the biogeochemical cycles of nitrogen $(\mathrm{N})$, phosphorus $(\mathrm{P})$, and oxygen $\left(\mathrm{O}_{2}\right)$ are regulated by the benthos (Rowe et al. 1975, Nixon et al. 1980, Fulweiler et al. 2010, Foster \& Fulweiler 2014). Pressures on the benthos such as hypoxic and anoxic conditions, nutrient loading, or organic matter deposition can lead to changes in $\mathrm{N}$, $\mathrm{P}$, and $\mathrm{O}_{2}$ processing and exchange with the water column (Nixon et al. 1980, Newell et al. 2002, Fulweiler et al. 2007, Middelburg \& Levin 2009, Hardison et al. 2015, Foster \& Fulweiler 2019), with important ecosystem level consequences for biodiversity (Turner et al. 1998, Glibert et al. 2016) and

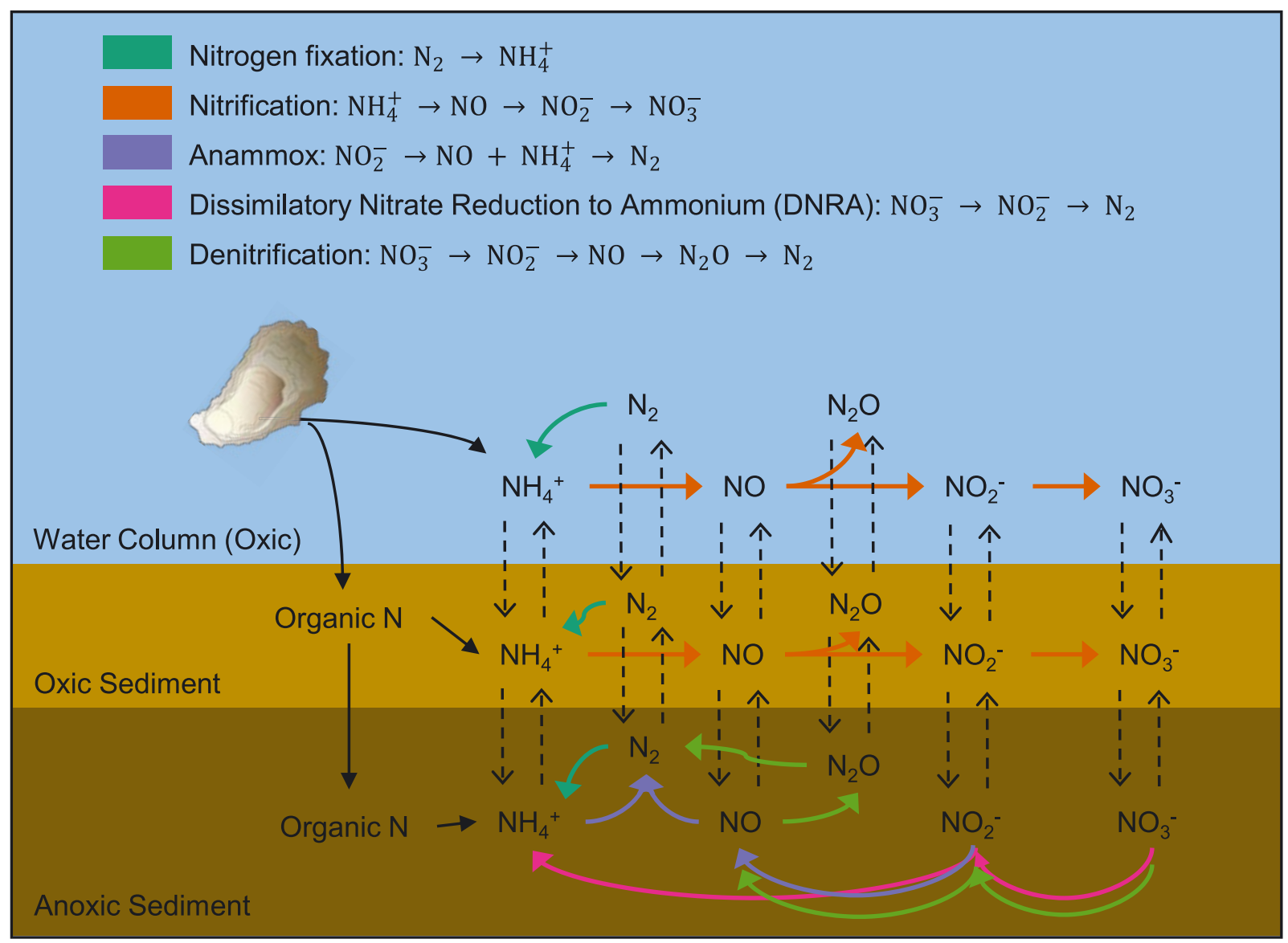

Fig. 1. Microbial nitrogen cycling network that contributes to net nitrogen fluxes in oyster habitats. Solid, colored arrows indicate metabolic processes, while dashed arrows show diffusion of nitrogen compounds between the oxic water column, oxic sediment, and anoxic sediment 
productivity (Rowe et al. 1975, Cloern 1982, Glibert et al. 2016). Like other bivalves, oysters excrete dissolved $\mathrm{N}$ and $\mathrm{P}$, and also move large quantities of organic material from the water column to the sediment below in biodeposits. The physical structure of oyster aquaculture may also influence deposition of organic material.

The pressure of additional nutrients and organic material in the sediments in the presence of large oyster populations could change $\mathrm{N}, \mathrm{P}$, and $\mathrm{O}_{2}$ cycling, as sediment microbial communities rely on inputs of nutrients and organic material from the water column. Yet, the net response to a change in the amount of these resources delivered to the sediment does not always lead to the same result. For example, in some cases adding organic matter can lead to a change in net metabolic rates, such as a shift from net nitrogen fixation to net denitrification (Newell et al. 2002, Fulweiler et al. 2007), while in other cases the signal is less clear, with either no change in net flux, or enhanced variability (Newell et al. 2002, Nizzoli et al. 2006). In this latter case, feedback loops and competition for resources may develop (Fig. 1), leading to oscillating and unpredictable exchange of $\mathrm{N}$ compounds between the sediment and water column. The microbial $\mathrm{N}$ cycle in sediments is complex, and often tightly coupled (Canfield et al. 2010, Kuypers et al. 2018; Fig. 1), with intense competition between microbes for $\mathrm{N}$ molecules, and waste products from one metabolic pathway are used as resources in others (Kraft et al. 2014, Kuypers et al. 2018). The release or consumption of various dissolved and gaseous $\mathrm{N}$ compounds between the sediment and water column is regulated by the predominant microbial metabolic pathway at a given point in time. The total amount of $N(\Sigma N)$ exchanged between sediment and water column may increase and remain constant over time under the pressure of oyster culture, but the contribution of various $\mathrm{N}$ compounds to $\Sigma \mathrm{N}$ can vary over time as the microbial community reorganizes, or feedback loops and competition develop. $\mathrm{P}$ is released from sediments in a dissolved form during decomposition and can also be adsorbed by sediments (Sundby et al. 1992). $\mathrm{O}_{2}$ is consumed by sediment microbial communities during aerobic decomposition processes and chemical weathering. Rates of P regeneration are typically higher when $\mathrm{O}_{2}$ concentrations are low (Ingall \& Jahnke 1994, Foster \& Fulweiler 2019), so addition of resources to the sediment that stimulate $\mathrm{O}_{2}$ consumption should also stimulate $P$ release.

In this study, we took advantage of an oyster farm where different farm areas had been used to raise oysters for varying lengths of time (i.e. an oyster aquaculture chronosequence, or space-for-time substitution) to test how the sediments responded to this pressure over time. By conducting all sampling at a single oyster farm, we could minimize the influence of confounding factors often associated with collecting samples at multiple locations (Walker et al. 2010). Using an in situ approach, we measured exchange rates of gaseous and dissolved forms of $\mathrm{N}$, dissolved $\mathrm{O}_{2}$ (DO), and dissolved $\mathrm{P}$ across the sediment water column interface at various ages of oyster aquaculture. We used mean fluxes and the magnitude of variance $\left(\sigma^{2}\right)$ of different ages of aquaculture to test the temporal response of sediments to the pressure of oyster aquaculture. If our results demonstrated different mean fluxes between various ages of culture but homogeneous variance, we would conclude that the system was able to rapidly restructure and adapt. If variance between age classes differed significantly, regardless of difference in mean, then we assumed that feedback loops and competition in the sediments drove fluxes to non-linearity. If there was no difference in flux mean or variance over time, then the sediments were resistant to the pressure of oyster aquaculture.

\section{MATERIALS AND METHODS}

\subsection{Sample site description and experimental design}

Ninigret Pond in Charlestown, Rhode Island (USA), is a shallow, microtidal lagoon separated from Block Island Sound by a thin sand and gravel barrier, with a water residence time of approximately $10 \mathrm{~d}$ (Hougham \& Moran 2007). While the majority of freshwater loading to the pond comes from groundwater (Masterson et al. 2007), only $6 \%$ of the $\mathrm{N}$ load is from this source (Moran et al. 2014). The oyster farm we sampled is adjacent to the barrier that separates Ninigret Pond from Block Island Sound and has an average water depth of $1 \mathrm{~m}$.

The sampled oyster farm employs a rack and bag technique, where oysters (Crassostrea virginica) are held in plastic mesh bags suspended approximately 10-20 cm from the sediment surface on PVC racks. Different portions of the 4 acre (ca. 1.6 ha) oyster farm had been in use for varying lengths of time. Each of our sites was similar in depth $(\sim 1 \mathrm{~m})$ and hydrodynamic condition. It is likely that oyster density at each site within the farm has varied over time, although the farm is managed so that as oysters 
grow, the number of individuals per $\mathrm{m}^{2}$ declines but biomass remains approximately the same. Marketsize oysters at the farm had a mean dry tissue mass of $2.93 \mathrm{~g} \mathrm{ind}^{-1}$ and were stocked at densities of approximately 250 ind. $\mathrm{m}^{-2}$, so the oyster biomass above our sediment sampling sites was approximately $732.5 \mathrm{~g}$ dry tissue $\mathrm{m}^{-2}$. We were unable to include the variance in oyster biomass in our study, but the presence of oyster aquaculture was likely constant over time. We elected to measure sediment $\mathrm{N}$ fluxes at 3 locations within the farm that had been in use for 2, 4, and $6 \mathrm{yr}$ during summer 2014. When re-sampled in the summer of 2015, these sites were then 3,5, and $7 \mathrm{yr}$ old. We also measured fluxes at a bare sediment, 'control' site (or 0 yr old site) approximately $10 \mathrm{~m}$ upstream of aquaculture gear, but still on the farm. Early on, sampling logistical issues led us to move our control site, and therefore we only have 2 flux measurements from bare sediments during summer 2014. Fluxes were measured from all 3 aquaculture sites over an $8 \mathrm{~d}$ period at the beginning of July 2014, and from all sites over $5 \mathrm{~d}$ in August 2014. In 2015, all sites were sampled from 29 June through 31 July, again over $10 \mathrm{~d}$ in August, and over a $4 \mathrm{~d}$ period in September. Resampling each age site improves confidence in observations, and helps to verify chronosequence assumptions (Walker et al. 2010).

We installed a $\mathrm{HOBO}^{\circledR}$ DO Logger (Onset Computer) directly upstream of the farm to record temperature and DO concentration every 15 min during both summers. Salinity was measured on sampling days using a Hach HQd equipped with a CDC401 probe (see Table S1 in the Supplement, www.int-res. com/articles/suppl/m646p013_supp.pdf).

\subsection{Sediment flux measurements}

We measured sediment $\mathrm{N}$ fluxes using an in situ approach after Humphries et al. (2016). With this method, we installed permanent PVC bases $(41 \mathrm{~cm}$ diameter, $15 \mathrm{~cm}$ inside depth, and $46 \mathrm{l}$ volume, depending on depth of sediment in the chamber base) in the sediment to which we attached incubation chambers on sampling days. We installed the bases directly beneath oyster aquaculture by first removing the bag holding oysters, removing enough sediment to allow the top of the base to be approximately level with the surrounding sediment, gently placing sediments back into the base, and replacing the oyster bag. During installation, we attempted to minimize disturbance to the sediment structure by removing large chunks of sediment, which were carefully placed back inside the base mostly intact. We allowed at least 1 mo (Kellogg et al. 2013, Humphries et al. 2016) for the sediment to equilibrate before our first flux incubations. Three bases were installed at each of the 4 sites, at least $1 \mathrm{~m}$ apart. Once the bases were installed, they were left in place for the duration of the experiment, except for re-positioning the control site rings, as described above.

On each incubation day, we measured fluxes from all 3 rings within each site. All incubations were conducted in the dark. For each ring, we removed the bag holding oysters, placed a $\mathrm{HOBO}{ }^{\odot}$ Pendant Temperature/Light 64K logger (Onset Computer) in the sediment in the middle of the ring, and then attached a $30 \mathrm{~cm}$ high, darkened plexiglass environmental chamber to the base. The temperature/light loggers were used to ensure that the incubation chamber remained dark and at a constant temperature for the duration of the incubation. Next, we inspected the inside of the chamber for any air bubbles, and removed any that were found. We then attached a clear plexiglass lid to the chamber, again careful to ensure no air bubbles were in the chamber, before placing a lid cover over the plexiglass lid to ensure that the chamber was fully dark. Lids were fitted with a stir bar and inflow and outflow ports, to which tubing with stopcocks was attached. The stir bar rotated at $40 \mathrm{rpm}$, and inflow tubing was attached to a carboy filled with unfiltered site water suspended above the incubation chamber.

We collected water samples at 5 time points throughout each incubation, spread out to allow for the DO within the chamber to drop at least $2.0 \mathrm{mg} \mathrm{l}^{-1}$ without the overall DO concentration dropping below $2.0 \mathrm{mg} \mathrm{l}^{-1}$ (Foster \& Fulweiler 2014, Humphries et al. 2016, Ray et al. 2019). The majority of incubations lasted between 1.5 and $2.5 \mathrm{~h}$. To collect samples, we simultaneously opened the stopcock on both the inflow and outflow tubing, allowing water from within the chamber to be collected and replaced with water from the carboy. At the end of sample collection, the stopcocks were closed. At each sampling time point, we collected samples for dissolved gas $\left(\mathrm{N}_{2}, \mathrm{~N}_{2} \mathrm{O}\right.$, and $\left.\mathrm{Ar}\right)$ and inorganic nutrient $\left(\mathrm{NH}_{4}{ }^{+}, \mathrm{NO}_{\mathrm{x}}\right.$, $\mathrm{PO}_{4}{ }^{3-}$ ) analysis. $\mathrm{N}_{2}, \mathrm{~N}_{2} \mathrm{O}$, and Ar samples were collected by filling $12 \mathrm{ml}$ Labco Exetainer vials $(\mathrm{n}=4)$ from the bottom, allowing them to overflow $\sim 3$ times before immediately preserving the sample with $25 \mu \mathrm{l}$ of saturated zinc chloride, and closing the exetainer with gas-tight septa. Two of the sample exetainers were used for $\mathrm{N}_{2}$ and $\mathrm{Ar}$ analysis, and the other 2 were used for $\mathrm{N}_{2} \mathrm{O}$ analysis. Dissolved nutrient sam- 
ples were collected by filtering $60 \mathrm{ml}$ of sample water through a Whatman GF/F filter $(0.7 \mu \mathrm{m})$ into 2 acidwashed polyethylene bottles (30 $\mathrm{ml}$ capacity each), which were immediately placed on ice until they were returned to the lab and frozen until analysis. $\mathrm{O}_{2}$ samples were collected at the beginning and end of the incubation, and analyzed immediately on site using a Hach HQd equipped with an LDO101 DO sensor.

Accounting for sample collection and occasional DO checks, replacement of chamber water over the course of each incubation was $<2 \%$. There was no change in temperature within incubation chambers, and all chambers remained dark for the duration of every incubation. We defined ambient dissolved nutrient concentrations as the initial measured concentrations in each chamber.

\subsection{Sediment characteristics}

We collected samples from each of the 4 sites to determine sediment chemical and physical characteristics in August and September 2015, immediately following incubations. Using an acid-washed $60 \mathrm{ml}$ plastic syringe with the tip cut off, we collected the top $0-1 \mathrm{~cm}$ of sediment from within each sampling ring, and stored these samples on ice in $50 \mathrm{ml}$ acid-washed plastic centrifuge tubes until returned to the lab, where they were frozen until analysis. Sediment samples were later analyzed for density, porosity, \% organic material, $\% \mathrm{C}$, and $\% \mathrm{~N}$. Density was calculated by measuring water displacement following the addition of a known mass of sediment, and porosity was calculated by dividing the difference in mass of sediment before and after drying in a $60^{\circ} \mathrm{C}$ oven by its density (Dalsgaard et al. 2000). The \% organic material was calculated as the percent difference in mass of sediment following combustion in a muffle furnace at $500^{\circ} \mathrm{C}$ for $4 \mathrm{~h}$. $\% \mathrm{C}$ and $\% \mathrm{~N}$ were estimated using an elemental analyzer (NC Technologies).

We repeated the sediment collection procedure with syringes and centrifuge tubes that were not acid-washed to collect sediment chlorophyll a (chl a) and phaeophytin samples in August 2015. These samples were stored at $-80^{\circ} \mathrm{C}$ until analysis. For analysis, we allowed the samples to thaw, added $25 \mathrm{ml}$ of $92 \%$ acetone to each, then sonicated each sample for $30 \mathrm{~s}$, and stored them in the dark at $4{ }^{\circ} \mathrm{C}$ for $24 \mathrm{~h}$ (Fagherazzi et al. 2014). We then removed $2 \mathrm{ml}$ of extract for fluorometric analysis of chl $a$ and phaeophytin concentration (Arar \& Collins 1997).
Sample mass varied depending on sediment density, but was typically between 2 and $5 \mathrm{~g}$.

Additionally, we collected samples for analysis of sediment porewater $\mathrm{NH}_{4}{ }^{+}$and $\mathrm{NO}_{\mathrm{x}}$ concentrations. We extracted porewater from $4 \mathrm{~cm}$ depth by applying light pressure to a stainless steel tube with a specially designed tip following the methods described by Berg \& McGlathery (2001). Porewater samples were handled, stored, and analyzed in the same way as $\mathrm{NH}_{4}{ }^{+}$and $\mathrm{NO}_{\mathrm{x}}$ flux samples (see Section 2.4).

\subsection{Sample analysis}

Sample $\mathrm{N}_{2}$ and Ar concentrations were determined using a quadrupole membrane inlet mass spectrometer (MIMS) following the $\mathrm{N}_{2} / \mathrm{Ar}$ technique (Kana et al. 1994). We multiplied the $\mathrm{N}_{2} / \mathrm{Ar}$ determined by the MIMS by the theoretical Ar concentration of the sample given its temperature and salinity to estimate sample $\mathrm{N}_{2}-\mathrm{N}$ concentration (Weiss 1970, Colt 1984, Fulweiler et al. 2007, Foster \& Fulweiler 2014).

$\mathrm{N}_{2} \mathrm{O}$ concentrations were analyzed using a headspace equilibration technique followed by gas chromatography (Foster \& Fulweiler 2016). First, we made a gas headspace in the sample exetainer by simultaneously removing $5 \mathrm{ml}$ of water sample and adding $5 \mathrm{ml}$ of ultra-high purity He using gas-tight glass syringes. The exetainer vial was then vigorously shaken for $10 \mathrm{~s}$ and allowed to equilibrate for at least $1 \mathrm{~h}$. Following equilibration, $4 \mathrm{ml}$ of sampleheadspace was removed using a gas-tight glass syringe and injected into a Shimadzu 2014 gas chromatograph equipped with an electron capture detector with ${ }^{63} \mathrm{Ni}$ source, and columns packed with HayeSep ${ }^{\circledR}$ and Shimalite ${ }^{\circledR}$. $\mathrm{N}_{2}$ was used as the carrier gas and $\mathrm{P} 5\left(5 \% \mathrm{CH}_{4}\right.$ and $\left.95 \% \mathrm{Ar}\right)$ as the electron capture detector make-up gas. The concentration of $\mathrm{N}_{2} \mathrm{O}$ in our samples was estimated by comparing the area under the peak generated for the sample against a standard curve of peak areas generated from 6 different concentrations of an externally mixed standard made up of $500 \mathrm{ppb} \mathrm{N}_{2} \mathrm{O}$ in $\mathrm{N}_{2}$ (Airgas). All standard curves had $\mathrm{R}^{2}$ values $\geq 0.995$, and the detection limit for $\mathrm{N}_{2} \mathrm{O}$ during sample analysis was $0.386 \mu \mathrm{M}$.

We analyzed concentrations of dissolved nutrients using high-resolution digital colorimetry on a Seal AutoAnalyzer 3. $\mathrm{NH}_{4}{ }^{+}, \mathrm{NO}_{\mathrm{x}}\left(\mathrm{NO}_{2}{ }^{-}+\mathrm{NO}_{3}{ }^{-}\right)$and $\mathrm{PO}_{4}{ }^{3-}$ were determined using SEAL methods G171-96, G173-96, and G175-96, respectively. Minimum detection limits during these analyses were $0.08 \mu \mathrm{M}$ $\mathrm{NH}_{4}{ }^{+}, 0.013 \mu \mathrm{M} \mathrm{NO}_{\mathrm{x}}$, and $0.01 \mu \mathrm{M} \mathrm{PO}_{4}{ }^{3-}$. 


\subsection{Flux calculation}

Fluxes of $\mathrm{N}_{2}, \mathrm{~N}_{2} \mathrm{O}, \mathrm{NH}_{4}{ }^{+}, \mathrm{NO}_{\mathrm{x}}$, and $\mathrm{PO}_{4}{ }^{3-}$ were estimated using a linear regression of sample concentration over time. The slope of the calculated regression line $\left(\mu \mathrm{M} \mathrm{h}^{-1}\right)$ was then converted to a sediment flux $\left(\mu \mathrm{mol} \mathrm{m}{ }^{-2} \mathrm{~h}^{-1}\right)$ :

Flux Rate $\left(\frac{\mu m o l}{m^{2} \times h}\right)=$

Slope of Regression $\left(\frac{\mu \mathrm{mol}}{\mathrm{l} \times \mathrm{h}}\right) \times$ Chamber Volume (l) Sediment Area $\left(\mathrm{m}^{2}\right)$

Fluxes were only considered significant when the regression $R^{2}$ was $\geq 0.65$ and $p \leq 0.10$ (Prairie 1996, Foster \& Fulweiler 2016, Humphries et al. 2016). We considered regression calculations with $\mathrm{R}^{2} \geq 0.65$ to indicate no flux, and assigned the flux a value of 0 (Foster \& Fulweiler 2016). No fluxes analyzed in this study behaved non-linearly. We estimated sediment $\mathrm{O}_{2}$ flux using a similar approach, but instead of using the slope calculated from a regression, we calculated the flux using the difference in measured $\mathrm{O}_{2}$ concentration between the beginning and end of the incubation.

Net $\mathrm{N}$ flux $(\Sigma \mathrm{N})$ was calculated as the sum of $\mathrm{N}_{2}$, $\mathrm{NH}_{4}{ }^{+}, \mathrm{N}_{2} \mathrm{O}$, and $\mathrm{NO}_{\mathrm{x}}$ fluxes. When 1 of the 4 constituents of the $\Sigma \mathrm{N}$ flux was missing, we did not calculate a $\Sigma \mathrm{N}$ value for that sampling event, and excluded it from our statistical analysis ( $\mathrm{n}=8$, or $14 \%$ of the incubations).

\subsection{Statistical analysis}

All statistical analyses were conducted in $\mathrm{R}$ version 3.3.2. We considered the results of statistical tests to be significant when $p \leq 0.05$. To test whether sediment beneath oyster aquaculture exchanged $\mathrm{N}$ compounds with the water column at different rates from bare sediment, and whether porewater $\mathrm{N}$ concentrations differed, we used a mixed model approach. First, we transformed our data so that we could assess their distribution and best meet the assumptions of mixed models (Bolker et al. 2009). Specifically, we shifted $\mathrm{N}_{2}$, $\mathrm{NH}_{4}{ }^{+}, \mathrm{NO}_{\mathrm{x}}, \Sigma \mathrm{N}$, and $\mathrm{PO}_{4}{ }^{3-}$ fluxes to be positive by adding 1 plus the absolute value of the lowest flux to all other fluxes of that type. All $\mathrm{O}_{2}$ fluxes were negative, so we mirrored them around 0 by multiplying by -1 (Zuur et al. 2009, Ray et al. 2019). $\mathrm{N}_{2} \mathrm{O}$ fluxes were mostly negative, so we again mirrored them around 0 , and then added the absolute value of the lowest mirrored flux to all other fluxes. We then tested whether the distributions of the transformed and shifted data best fit a normal, lognormal, or gamma distribution using the 'fitdistrplus' package in $\mathrm{R}$ (Delignette-Muller \& Dutang 2015; Table S2). $\mathrm{O}_{2}$ and $\mathrm{PO}_{4}{ }^{3-}$ fluxes were log-normal, so we transformed them using a log transformation. Raw $\mathrm{N}_{2} \mathrm{O}$ data best fit a gamma distribution, but not all generalized linear models (GLMs) and generalized linear mixed models (GLMMs) converged when using this distribution, so we applied a square root transformation, after which the data best fit a normal distribution and all models created converged (Table S2).

Next, we created 8 GLMs and 8 GLMMs using the 'Ime4' package in R (Bates et al. 2015). Each GLM used the presence or absence of oyster aquaculture as a fixed effect, with the addition of temperature, salinity, or month to improve the predictive power of the model. We repeated this process to create GLMMs, with the addition of the individual sampling ring as a random effect in each model to test for influence of repeated measures (Zuur et al. 2009). For all flux measurements, the random effect did not improve the model, indicating that each flux measurement was independent, and that we could consider samples collected in summer 2014 and summer 2015 as different ages of aquaculture. The sampling ring random effect was included in the best model to describe porewater $\left[\mathrm{NH}_{4}^{+}\right]$when comparing bare sediments and those beneath aquaculture (Tables S3 \& S4). We then selected the 2 best models using Akaike's information criterion (AIC; Sakamoto et al. 1986), and compared them using a likelihood ratio test. When the best 2 models were not significantly different from each other, we elected to use the simpler, more parsimonious model (Table S3). Finally, we tested whether sediment fluxes and porewater $\mathrm{N}$ concentrations were significantly different between sites with and without oyster aquaculture using pairwise least-square means tests via the 'emmeans' package in R (Lenth 2018). To test whether the length of time aquaculture had been in place influenced fluxes and porewater $\mathrm{N}$ concentration, we repeated the same steps, but substituted the age of oyster culture for the presence or absence of oyster culture in all of our models (Tables S4 \& S5). We treated site age as a categorical variable instead of a linear variable.

We used Fligner-Killeen tests (Conover et al. 1981) to test for homogeneity of variance $\left(\sigma^{2}\right)$ between fluxes measured from bare sediments and those beneath oyster aquaculture. Sediment properties were compared between bare sediment and sediment beneath oyster aquaculture using 2-tailed $t$ tests. We tested for relationships between sediment 
properties and porewater nutrient content using Pearson correlations.

All sediment flux data and associated sediment properties used in this study are accessible online through the Figshare repository under access number https://doi.org.10.6084/m9.figshare.12174636.v1.

\section{RESULTS}

\subsection{Site characterization}

Sediment characteristics were typically similar between the different aged sites (Table 1). We found no statistical differences for any characteristic between bare sediments, and those beneath oyster aquaculture, although sediment chl $a$ and phaeophytin content tended to increase in sediment beneath aquaculture in place for longer periods of time. Concentrations of dissolved nutrients in the water overlying sediment were relatively low throughout the study (Table $\mathrm{S} 6$ ), with a mean $\pm \mathrm{SE} \mathrm{NH}_{4}{ }^{+}$concentration of $1.39 \pm 0.14 \mu \mathrm{M}, \mathrm{NO}_{\mathrm{x}}$ concentration of $0.10 \pm$ $0.01 \mu \mathrm{M}$, and $\mathrm{PO}_{4}{ }^{3-}$ concentration of $0.27 \pm 0.02 \mu \mathrm{M}$.

\subsection{Sediment biogeochemical cycling along an oyster aquaculture chronosequence}

The total amount of $N(\Sigma N)$ exchanged between the sediment and water column was higher beneath oyster aquaculture than bare sediment $(p<0.001)$, with bare sediment acting as a net $\mathrm{N}$ sink and all ages of aquaculture acting as a net $\mathrm{N}$ source to the water column (Fig. 2a,b). There was no difference in $\mathrm{O}_{2}$ consumption between bare sediments and sediments beneath oyster aquaculture when comparing treatments $(\mathrm{p}=0.542)$, but there was a stimulation in the rate of $\mathrm{O}_{2}$ consumption at the $4 \mathrm{yr}$ old site, although this stimulation appears to only last for a couple of years (Fig. 2c,d). Similarly, we observed no difference in $\mathrm{PO}_{4}{ }^{3-}$ fluxes $(\mathrm{p}=0.814)$ between bare sediments $\left(9.86 \pm 9.86 \mu \mathrm{mol} \mathrm{PO}_{4}{ }^{3-} \mathrm{m}^{-2} \mathrm{~h}^{-1}\right)$ and sediments beneath oyster aquaculture (7.32 \pm $4.07 \mu \mathrm{mol} \mathrm{PO}_{4}{ }^{3-} \mathrm{m}^{-2} \mathrm{~h}^{-1}$ ), although there was only 1 non-zero flux from bare sediments, while those beneath aquaculture released $\mathrm{PO}_{4}{ }^{3-}$ slightly more frequently (Fig. 2e,f). There were no statistical differences in $\mathrm{PO}_{4}{ }^{3-}$ flux between sediments beneath aquaculture for different lengths of time.

Bare sediments shifted from net nitrogen fixation $\left(-78.92 \pm 58.05 \mu \mathrm{mol} \mathrm{N} \mathrm{N}_{2}-\mathrm{N} \mathrm{m}^{-2} \mathrm{~h}^{-1}\right)$ to net denitrification $\left(366.19 \pm 117.74 \mu \mathrm{mol} \mathrm{N} \mathrm{N}_{2}-\mathrm{N} \mathrm{m}^{-2} \mathrm{~h}^{-1} ; \mathrm{p}=0.014\right.$; Fig. 3a) beneath oyster aquaculture. While each age of aquaculture demonstrated $\mathrm{N}_{2}$ release (i.e. net denitrification), variance in the magnitude of fluxes was high between replicate sites and sampling events, and only the $2 \mathrm{yr}$ old aquaculture site had a mean $\mathrm{N}_{2}$ flux different from bare sediment (Fig. 3b). Mean $\mathrm{NH}_{4}{ }^{+}$fluxes followed a similar pattern with net $\mathrm{NH}_{4}{ }^{+}$ consumption by bare sediment $(-42.06 \pm 17.67 \mu \mathrm{mol}$ $\mathrm{NH}_{4}{ }^{+} \mathrm{m}^{-2} \mathrm{~h}^{-1}$ ) and net release at aquaculture sites $\left(192.06 \pm 119.20 \mu \mathrm{mol} \mathrm{NH}{ }_{4}^{+} \mathrm{m}^{-2} \mathrm{~h}^{-1}\right)$. Despite this shift, there was no statistical difference in $\mathrm{NH}_{4}{ }^{+}$fluxes

Table 1. Sediment characteristics of different aged oyster aquaculture sites at 0-1 cm depth in August and September 2015. Data are mean $\pm \mathrm{SE}$

\begin{tabular}{|c|c|c|c|c|c|}
\hline $\begin{array}{l}\text { Sediment } \\
\text { characteristic }\end{array}$ & Month & $\begin{array}{c}0 \mathrm{yr} \\
\text { (Control) }\end{array}$ & $3 y r$ & $5 \mathrm{yr}$ & $7 \mathrm{yr}$ \\
\hline $\begin{array}{l}\text { Organic material } \\
\text { (\% loss on ignition) }\end{array}$ & $\begin{array}{c}\text { August } \\
\text { September }\end{array}$ & $\begin{array}{l}1.62 \pm 0.27 \\
1.80 \pm 0.48\end{array}$ & $\begin{array}{l}0.78 \pm 0.02 \\
0.37 \pm 0.12\end{array}$ & $\begin{array}{l}1.77 \pm 0.47 \\
1.64 \pm 1.00\end{array}$ & $\begin{array}{l}2.01 \pm 0.11 \\
2.07 \pm 0.21\end{array}$ \\
\hline Total C (\%) & $\begin{array}{c}\text { August } \\
\text { September }\end{array}$ & $\begin{array}{l}0.66 \pm 0.23 \\
0.46 \pm 0.07\end{array}$ & $\begin{array}{l}0.23 \pm 0.07 \\
0.29 \pm 0.01\end{array}$ & $\begin{array}{l}0.50 \pm 0.05 \\
1.13 \pm 0.12\end{array}$ & $\begin{array}{l}0.87 \pm 0.13 \\
1.10 \pm 0.23\end{array}$ \\
\hline Total N (\%) & $\begin{array}{c}\text { August } \\
\text { September }\end{array}$ & $\begin{array}{l}0.07 \pm 0.02 \\
0.04 \pm 0.01\end{array}$ & $\begin{array}{l}0.02 \pm 0.01 \\
0.03 \pm 0.00\end{array}$ & $\begin{array}{l}0.04 \pm 0.00 \\
0.11 \pm 0.02\end{array}$ & $\begin{array}{l}0.10 \pm 0.02 \\
0.08 \pm 0.02\end{array}$ \\
\hline $\mathrm{C}: \mathrm{N}$ ratio & $\begin{array}{c}\text { August } \\
\text { September }\end{array}$ & $\begin{array}{l}10.59 \pm 0.37 \\
15.89 \pm 3.72\end{array}$ & $\begin{array}{l}10.08 \pm 0.52 \\
10.08 \pm 0.52\end{array}$ & $\begin{array}{l}14.51 \pm 1.39 \\
12.41 \pm 0.78\end{array}$ & $\begin{array}{l}10.25 \pm 0.64 \\
18.55 \pm 7.81\end{array}$ \\
\hline Porosity & $\begin{array}{c}\text { August } \\
\text { September }\end{array}$ & $\begin{array}{l}0.48 \pm 0.02 \\
0.53 \pm 0.01\end{array}$ & $\begin{array}{l}0.44 \pm 0.02 \\
0.49 \pm 0.03\end{array}$ & $\begin{array}{l}0.55 \pm 0.01 \\
0.63 \pm 0.01\end{array}$ & $\begin{array}{l}0.53 \pm 0.04 \\
0.52 \pm 0.04\end{array}$ \\
\hline Density $\left(\mathrm{g} \mathrm{cm}^{-3}\right)$ & $\begin{array}{c}\text { August } \\
\text { September }\end{array}$ & $\begin{array}{l}1.69 \pm 0.10 \\
1.72 \pm 0.04\end{array}$ & $\begin{array}{l}1.67 \pm 0.11 \\
1.63 \pm 0.15\end{array}$ & $\begin{array}{l}1.83 \pm 0.09 \\
1.47 \pm 0.02\end{array}$ & $\begin{array}{l}1.55 \pm 0.02 \\
1.13 \pm 0.23\end{array}$ \\
\hline Chlorophyll a $\left(\mu \mathrm{g} \mathrm{cm}^{-2}\right)$ & August & $8.36 \pm 4.32$ & $5.91 \pm 1.87$ & $11.12 \pm 1.99$ & $15.03 \pm 5.14$ \\
\hline Phaeophytin $\left(\mu \mathrm{g} \mathrm{cm}^{-2}\right)$ & August & $4.33 \pm 1.68$ & $3.09 \pm 1.40$ & $12.83 \pm 1.78$ & $26.42 \pm 10.38$ \\
\hline
\end{tabular}



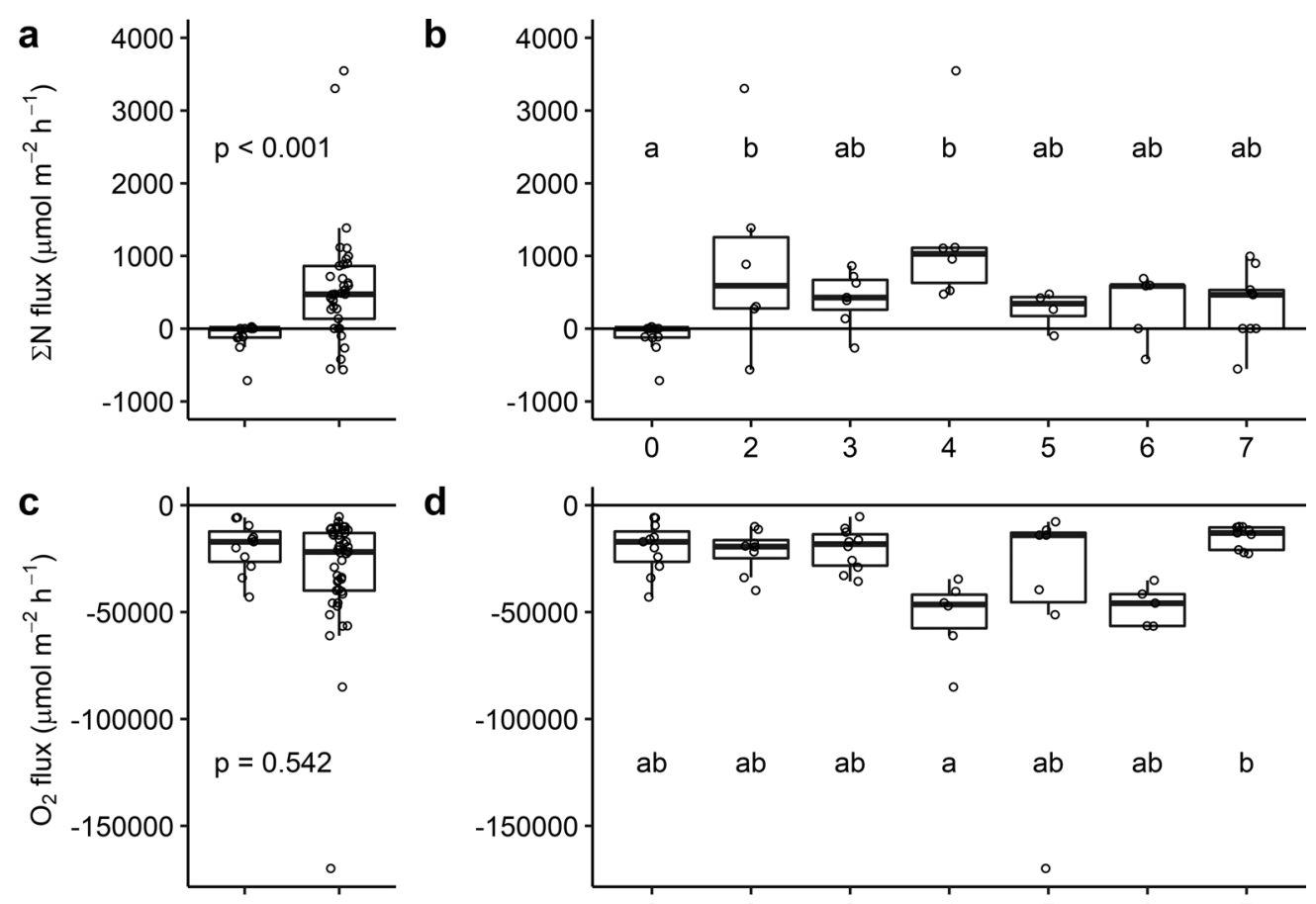

d
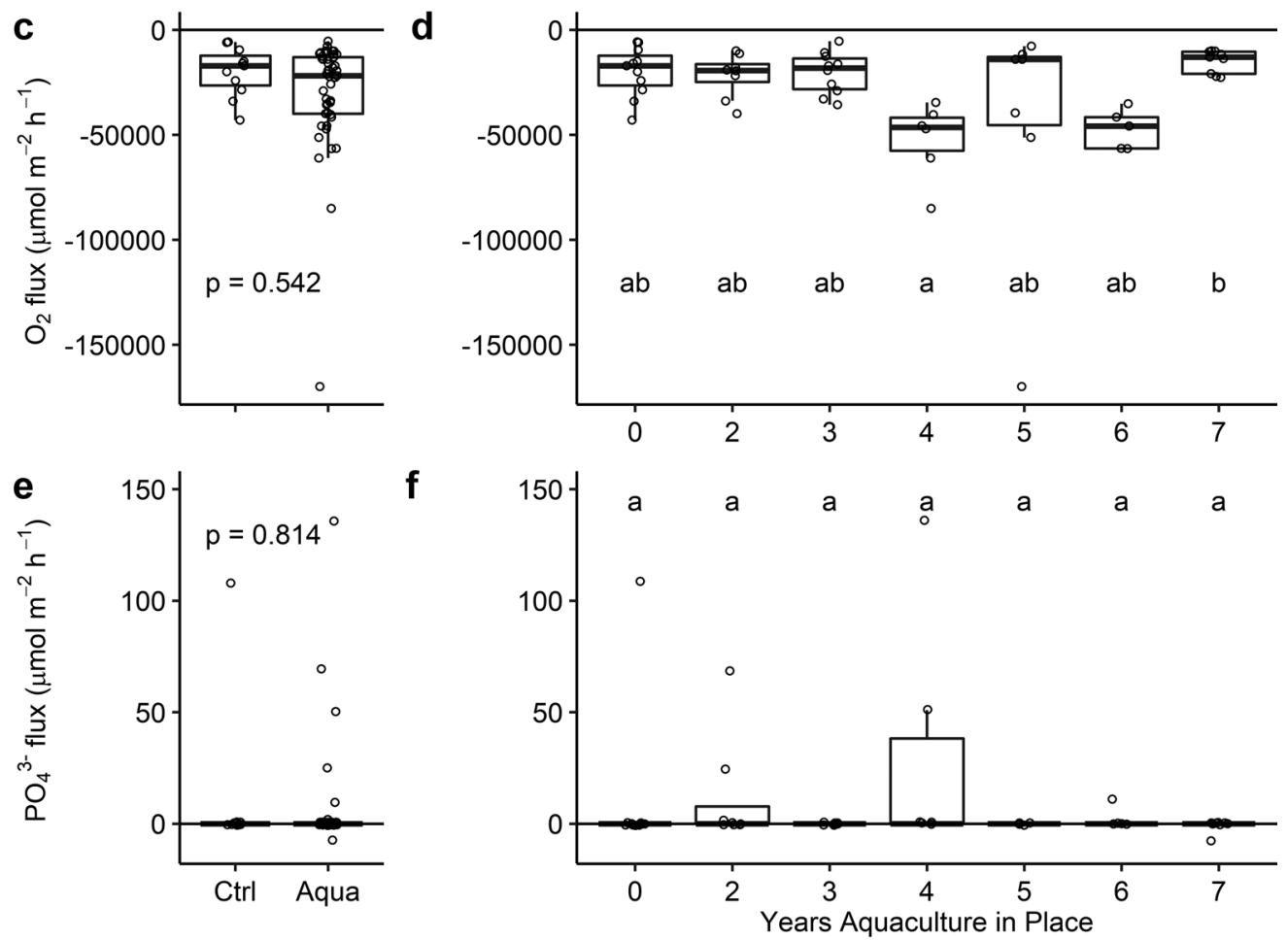

Fig. 2. Net nitrogen ( $\Sigma \mathrm{N}_{i}$ sum of $\mathrm{N}_{2}, \mathrm{~N}_{2} \mathrm{O}, \mathrm{NH}_{4}{ }^{+}$, and $\mathrm{NO}_{\mathrm{x}}$ fluxes), oxygen, and phosphorus fluxes (a,c,e) from bare sediment ('Ctrl') and sediment beneath oyster aquaculture and $(\mathrm{b}, \mathrm{d}, \mathrm{f})$ over the length of time oyster aquaculture has been in place. Solid bar: median; box: 25th-75th percentile (IQR); whiskers: max./min. values $\leq 1.5 x$ IQR above/below box; circles: outliers. P-values indicate the difference between control and aquaculture sites, while aquaculture ages with the same letter are not significantly different ( $p \leq 0.05$; Table S5 in the Supplement, www.int-res.com/articles/suppl/m646p013_supp.pdf) from each other following least square means

between control and aquaculture sites $(p=0.416$; Fig. 4a). This lack of statistical difference is likely driven by the high variance in $\mathrm{NH}_{4}{ }^{+}$fluxes in sediment beneath aquaculture, which frequently switched between net $\mathrm{NH}_{4}{ }^{+}$release and consumption, with a significant difference in variance between the 2 treatments $(\mathrm{p}<0.001)$. The magnitude of $\mathrm{NH}_{4}{ }^{+}$fluxes from sediment beneath oyster aquaculture, regardless of direction, was greater than from bare sediment, with high rates of both release and consumption for all lengths of time aquaculture had been in place (Fig. 4). Neither $\mathrm{N}_{2} \mathrm{O}\left(\mathrm{p}=0.922\right.$; Fig. 3) nor $\mathrm{NO}_{\mathrm{x}}$ fluxes ( $\mathrm{p}=$
0.486; Fig. 4) changed when oyster aquaculture was present, and did not change with the length of time oyster aquaculture had been in place.

Porewater $\mathrm{NH}_{4}{ }^{+}$concentrations in sediments beneath oyster aquaculture $\left(100.60 \pm 15 \mu \mathrm{M} \mathrm{NH}{ }_{4}^{+}\right)$ were significantly higher $(\mathrm{p}=0.001)$ than in bare sediments $\left(30.03 \pm 5.72 \mu \mathrm{M} \mathrm{NH}_{4}{ }^{+}\right)$, and concentrations increased in sediments that had been beneath aquaculture for a longer period of time (Fig. 4e,f). We were unable to quantify porewater $\mathrm{NO}_{\mathrm{x}}$ concentrations due to suspected interference from sulfides during colorimetric analysis. 

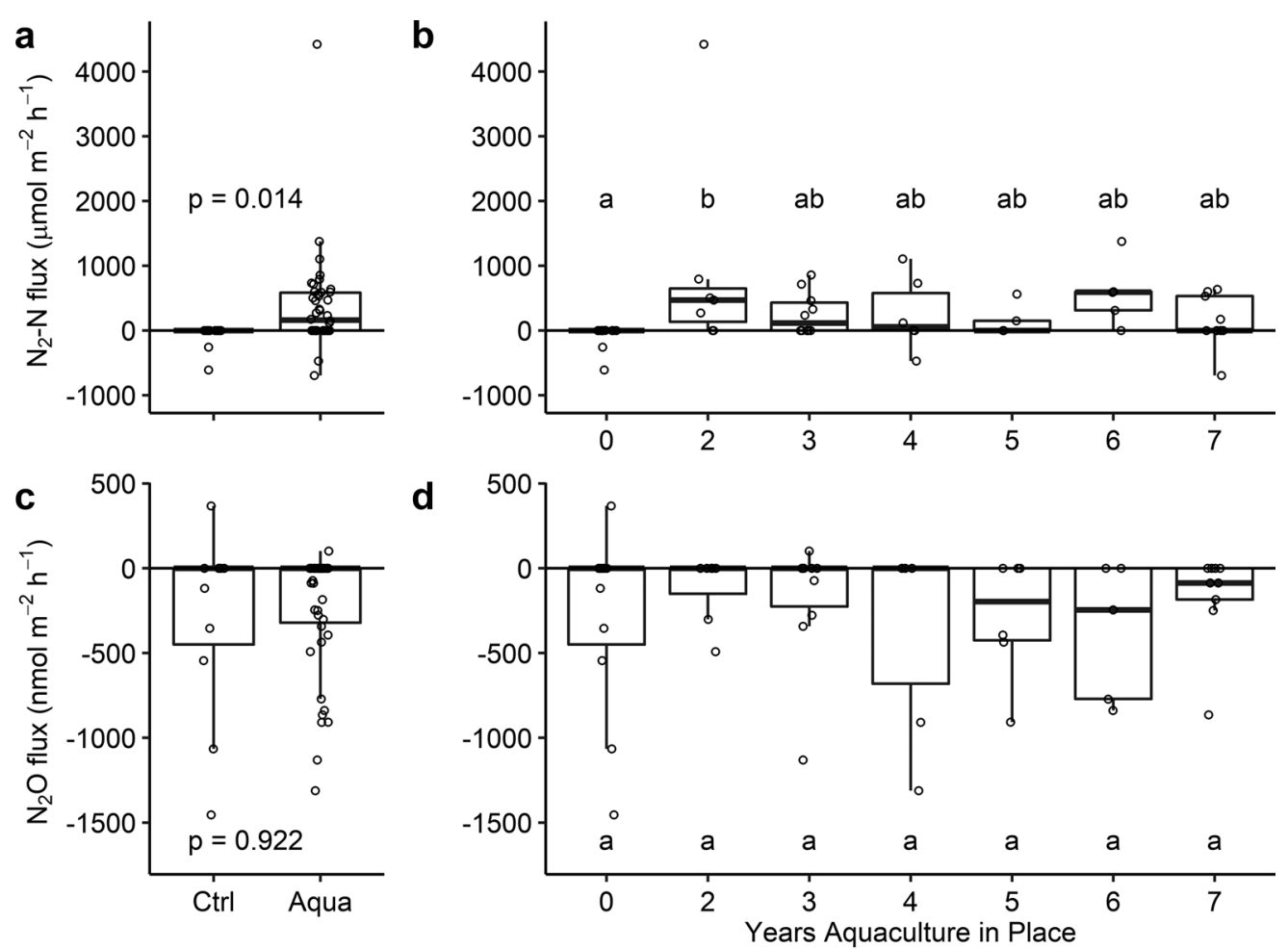

Fig. 3. Net fluxes of dinitrogen $\left(\mathrm{N}_{2}\right)$ and nitrous oxide $\left(\mathrm{N}_{2} \mathrm{O}\right)(\mathrm{a}, \mathrm{c})$ from bare sediment ('Ctrl'), and sediment beneath oyster aquaculture and $(b, d)$ over the length of time oyster aquaculture has been in place. Solid bar: median; box: 25 th-75th percentile (IQR); whiskers: max./min. values $\leq 1.5 \mathrm{x}$ IQR above/below box; circles: outliers. P-values indicate the difference between control and aquaculture sites, while aquaculture ages with the same letter are not significantly (p $\leq 0.05 ;$ Table S5) different from each other following least square means

There were few significant relationships between surface sediment properties and fluxes. We found a positive relationship between sediment C:N and $\mathrm{N}_{2}$ flux ( $\mathrm{p}=0.015, \mathrm{r}=0.52)$ and a negative relationship between sediment \% organic matter and $\mathrm{N}_{2} \mathrm{O}$ flux $(\mathrm{p}=0.022, \mathrm{r}=-0.50 ;$ Table S7).

\subsection{Enhanced variance in biogeochemical cycling beneath oyster aquaculture}

There was greater variance $\left(\sigma^{2} ;\right.$ Table S8) in $\Sigma \mathrm{N}$ $(\mathrm{p}=0.010), \mathrm{N}_{2}(\mathrm{p}=0.002)$, and $\mathrm{NH}_{4}{ }^{+}(\mathrm{p}<0.001)$ fluxes from sediment beneath oyster aquaculture relative to bare sediment. Variance was homogeneous between bare sediment and sediment beneath oyster aquaculture for fluxes of $\mathrm{O}_{2}(\mathrm{p}=0.142), \mathrm{N}_{2} \mathrm{O}(\mathrm{p}=0.314), \mathrm{NO}_{\mathrm{x}}$ $(\mathrm{p}=0.879)$, and $\mathrm{PO}_{4}{ }^{3-}(\mathrm{p}=0.643)$.

When the monthly fluxes from each benthic ring at the bare and $7 \mathrm{yr}$ old sites were visualized in a 2 dimensional plane, sediment biogeochemical processes tended to have similar 'trajectories' in terms of $\Sigma \mathrm{N}$ and $\mathrm{O}_{2}$ fluxes within their age group (Fig. 5). However, there was a greater degree of variance whether $\mathrm{N}$ was recycled $\left(\mathrm{NH}_{4}{ }^{+}\right.$flux $)$or removed $\left(\mathrm{N}_{2}\right.$ flux) from the system, in sediments at the $7 \mathrm{yr}$ old site (Fig. 6).

\section{DISCUSSION}

\subsection{How do sediments respond to pressure from oyster aquaculture over time?}

The results of our study show that the pressure from oyster aquaculture shifts sediments from a net sink of $\mathrm{N}$ to a net source of $\mathrm{N}$ to the water column. However, while there was a shift in the net exchange of $N(\Sigma N)$ between the sediment and water column, the dominant form of $\mathrm{N}$ contributing to this change at any point in time was unpredictable, as both $\mathrm{N}_{2}$ and $\mathrm{NH}_{4}{ }^{+}$fluxes increased in variability following implementation of oyster aquaculture. Bare sediments were dominated by net nitrogen fixation at all sampling dates, but following the implementation of oyster aquaculture, net $\mathrm{N}_{2}$ fluxes became more dynamic, with more net denitrification measurements, in addition to some nitrogen fixation events (Figs. $2 \& 6$ ). 

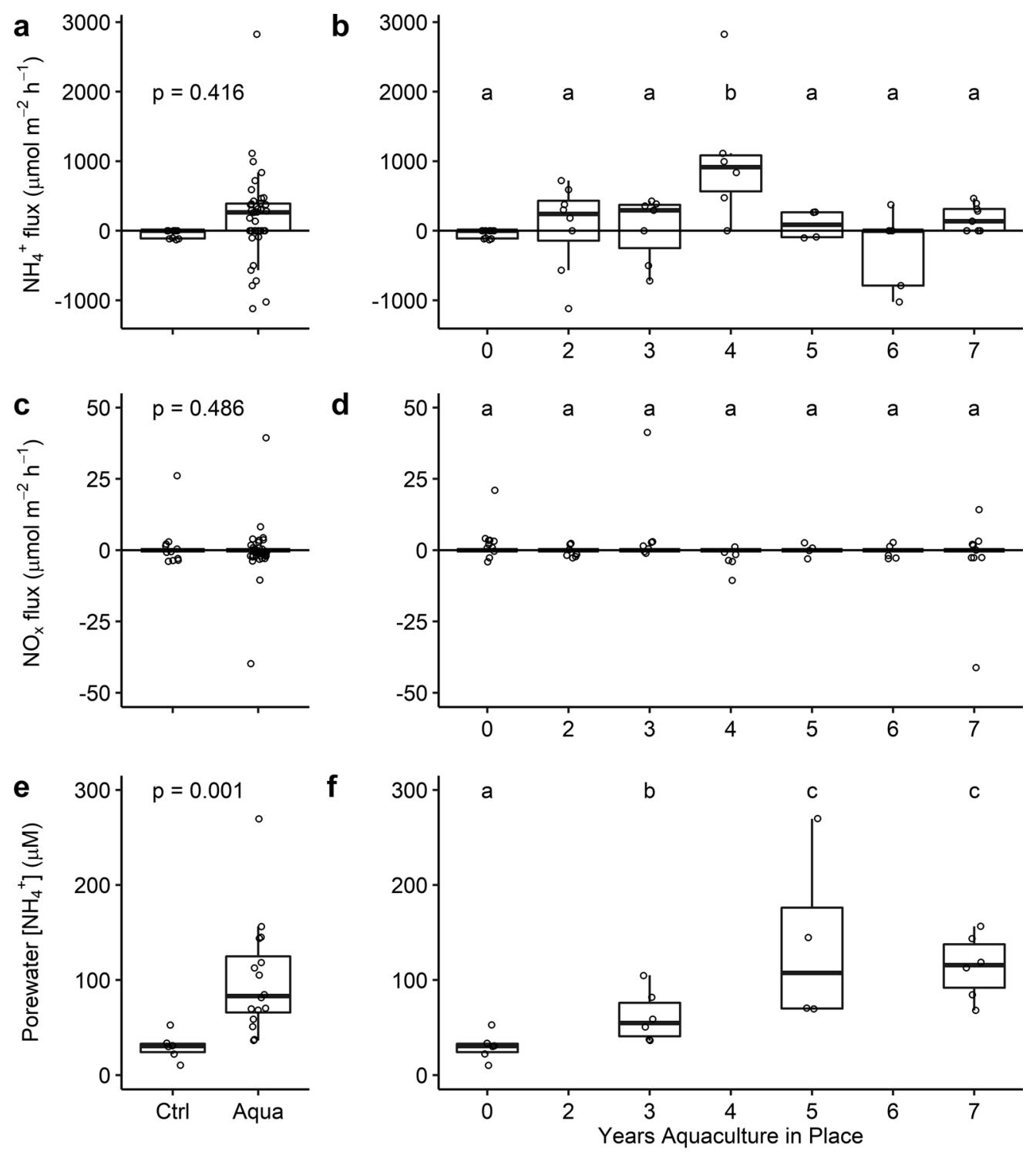

Fig. 4. Net fluxes of ammonium $\left(\mathrm{NH}_{4}{ }^{+}\right)$, combined nitrate-nitrite $\left(\mathrm{NO}_{\mathrm{x}}\right)$, and porewater $\mathrm{NH}_{4}{ }^{+}$concentration from (a,c,e) bare sediment ('Ctrl') and sediment beneath oyster aquaculture and ( $b, d, f)$ over the length of time oyster aquaculture has been in place. Solid bar: median; box: 25th-75th percentile (IQR); whiskers: max./min. values $\leq 1.5 x$ IQR above/below box; circles: outliers. P-values indicate the difference between control and aquaculture sites, while aquaculture ages with the same letter are not significantly ( $\mathrm{p} \leq 0.05$; Table S5) different from each other following least square means

Similarly, bare sediments were a net $\mathrm{NH}_{4}{ }^{+}$sink, and became more variable after the installation of aquaculture, oscillating over both an annual (Fig. 4) and monthly (Fig. 6) time frame, with high rates of both consumption and release to the water column. There was no clear change in sediment $\mathrm{O}_{2}$ processing between bare sediment and sediment beneath oyster aquaculture, although sediment $\mathrm{O}_{2}$ consumption was stimulated at the $4-6$ yr old sites, before returning to baseline rates at the $7 \mathrm{yr}$ old site. We did not measure any shifts or non-linear patterns in sediment $\mathrm{P}$ cycling. Taken together, these results demonstrate the development of non-linearity in sediment $\mathrm{N}$ and $\mathrm{O}_{2}$ processes following implementation of oyster aquaculture.

The high degree of variance and rapid (monthly) change in the dominant $\mathrm{N}$ product released from sediments beneath oyster aquaculture could be driven either by intense competition for $\mathrm{N}$ resources, or by processes which regulate the activity of different microbial groups, such as changes in the concentration of inhibiting agents. It is also possible that sedi- 


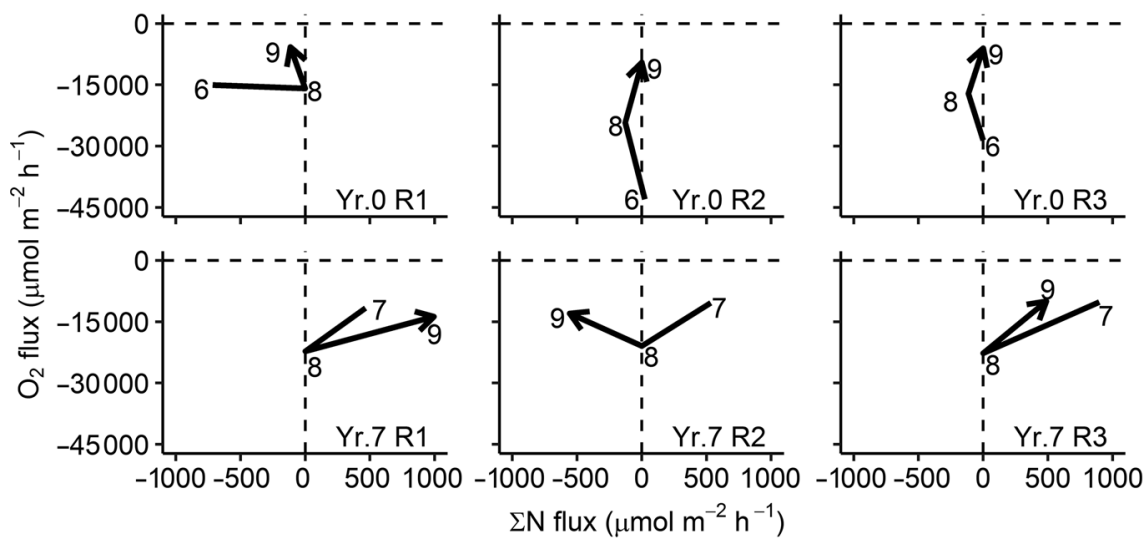

Fig. 5. Trajectory of sediment $\Sigma \mathrm{N}$ (sum of $\mathrm{N}_{2}, \mathrm{~N}_{2} \mathrm{O}, \mathrm{NH}_{4}{ }^{+}$, and $\mathrm{NO}_{\mathrm{x}}$ fluxes) and $\mathrm{O}_{2}$ fluxes at the bare sediment site and the $7 \mathrm{yr}$ old aquaculture site in summer 2015. The label in the bottom right corner of each panel indicates the benthic ring ID, and the numbers on the plot indicate the month in which the flux was measured (control rings were sampled on 30 June)

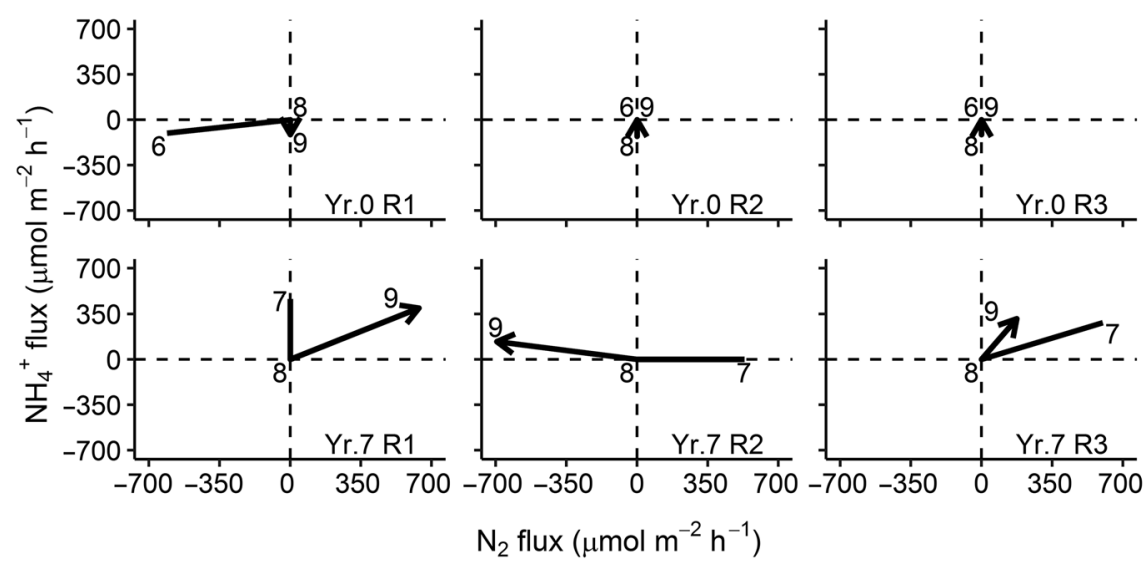

Fig. 6. Trajectory of sediment $\mathrm{N}_{2}$ and $\mathrm{NH}_{4}{ }^{+}$fluxes at the bare sediment site and the $7 \mathrm{yr}$ old aquaculture site in summer 2015. The label in the bottom right corner of each panel indicates the benthic ring ID, and the numbers on the plot indicate the month in which the flux was measured (control rings were sampled on 30 June)

ments under oyster aquaculture for varying lengths of time become more responsive to organic matter loading, so monthly changes in phytoplankton availability, or even community structure, may lead to rapid change. A combination of both of these factors likely contributed to our observations. We recorded only 1 flux of $\mathrm{NO}_{\mathrm{x}}$ out of the sediment and almost exclusive uptake of $\mathrm{N}_{2} \mathrm{O}$ by sediments, demonstrating they were primed for denitrification, and that competition for resources was high, as net $\mathrm{N}_{2} \mathrm{O}$ release from sediments indicates inefficient nitrification and denitrification (Seitzinger \& Nixon 1985, Firestone \& Davidson 1989). Denitrification was likely the dominant $\mathrm{N}$ reduction pathway, as $\mathrm{C}: \mathrm{N}$ ratios were low at all sites, favoring denitrification over dissimilatory nitrate reduction to ammonium (DNRA) (Tiedje 1988, Burgin \& Hamilton 2007, Kraft et al. 2014, Hardison et al. 2015). However, occasional buildup of hydrogen sulfide $\left(\mathrm{H}_{2} \mathrm{~S}\right)$ created during dissimilatory sulfate $\left(\mathrm{SO}_{4}{ }^{2-}\right)$ reduction may have allowed for microbes that use alternative $\mathrm{N}$-cycling pathways to persist, or even occasionally increase in abundance, leading to some of the monthly variance we observed in in $\mathrm{N}_{2}$ fluxes. Water column $\mathrm{NO}_{\mathrm{x}}$ concentrations were always low during our sampling (Table S6), and it is possible that $\mathrm{SO}_{4}{ }^{2-}$ reduction of organic material may have occasionally proceeded more rapidly than $\mathrm{NO}_{\mathrm{x}}$ reduction, leading to $\mathrm{H}_{2} \mathrm{~S}$ accumulation in sediments. $\mathrm{H}_{2} \mathrm{~S}$ is known to accumulate in estuarine sediments, and is a powerful inhibitor of microbial processes including nitrification (Joye \& Hollibaugh 1995) and the final 2 steps of denitrification (Sørensen et al. 1980) which yield $\mathrm{N}_{2} \mathrm{O}$ and $\mathrm{N}_{2}$ (Fig. 1).

We expected that the presence of oyster aquaculture would change sediment physical and chemical properties, but found no statistically significant change in sediment characteristics over time, except for an increase in porewater $\mathrm{NH}_{4}^{+}$concentration with aquaculture age. Despite this lack of change, we still recorded significantly greater $\Sigma \mathrm{N}$ flux in Years 2 and 4 relative to the control site. The addition of organic material to sediments - as may be expected beneath oyster aquaculture - is not always reflected in a change in sediment $\mathrm{C}: \mathrm{N}$ ratios, and $\% \mathrm{~N}$ and $\% \mathrm{C}$ following organic matter addition (Kristensen et al. 1995). In fact, we found that porewater $\mathrm{NH}_{4}{ }^{+}$concentrations were typically 30-100 times higher than $\mathrm{NH}_{4}{ }^{+}$concentrations in the overlying water on sampling days, and porewater $\mathrm{NH}_{4}{ }^{+}$concentrations also increased the longer aquaculture had been in place, reflecting decomposition of oyster biodeposits. There was no relationship between porewater $\mathrm{NH}_{4}{ }^{+}$concentration and $\mathrm{NH}_{4}{ }^{+}$ flux, suggesting that as particulates were buried and decomposed, the released $\mathrm{NH}_{4}{ }^{+}$did not diffuse to the sediment surface, and was effectively trapped, or used in coupled nitrification-denitrification. 


\subsection{Comparison with other studies}

In this study, we found that sediments beneath oyster aquaculture were typically a net $\mathrm{N}$ source to the water column, while bare sediment was a net $\mathrm{N}$ consumer; however, the processes contributing to these differences varied over the age of aquaculture. Similar biogeochemical responses to pressure have also been reported for other ecosystems. Chronic warming of soils in a temperate hardwood forest over $26 \mathrm{yr}$ increased $\mathrm{CO}_{2}$ emissions for the first $10 \mathrm{yr}$, after which warmed soils released the same amount or less $\mathrm{CO}_{2}$ than un-warmed soils, before returning to high $\mathrm{CO}_{2}$ release (Melillo et al. 2017). Tucker et al. (2014) reported non-linear patterns of sediment $\mathrm{N}_{2}$ and $\mathrm{NH}_{4}{ }^{+}$release in Boston Harbor (USA) following reductions in wastewater loading, potentially demonstrating hysteresis between ecosystem states following removal of wastewater loading pressure. On the other hand, long-term monitoring of sediment $\mathrm{N}_{2}$ fluxes in a temperate estuary (Narragansett Bay, USA) reveals the potential for annual switches between net denitrification and net nitrogen fixation in the summertime, regulated by water column chl a concentrations (Fulweiler \& Heiss 2014). These contrasting results require further investigation into thresholds and factors responsible for regulating whether sediments will resist pressures, respond with rapid re-organization, or develop feedback loops and non-linear dynamics. Understanding these factors is an important next step in developing predictive models and forecasts of future $\mathrm{N}$ and $\mathrm{C}$ cycling under various pressures, ranging from nutrient loading to ocean acidification and warming.

Previous studies measuring biogeochemical processes in sediments beneath oyster aquaculture report conflicting results. As an example, some studies found increased sediment denitrification (Humphries et al. 2016, Vieillard 2017, Lunstrum et al. 2018), no change (Mortazavi et al. 2015, Erler et al. 2017), or decreased denitrification beneath oyster culture (Higgins et al. 2013). There is similar disagreement in regard to whether DNRA is (Erler et al. 2017, Lunstrum et al. 2018), or is not (Vieillard 2017), altered in the presence of oyster aquaculture, and how oyster aquaculture regulates sediment $\mathrm{O}_{2}$ consumption. Fewer studies have measured whether $\mathrm{PO}_{4}{ }^{3-}$ fluxes change in the presence of oysters and oyster aquaculture. Kellogg et al. (2013) found significant stimulation of $\mathrm{PO}_{4}{ }^{3-}$ release from sediments beneath a restored oyster reef, at rates 10 times those found in this study. While these differences may be due to differences in sediment characteristics and resistance of microbial networks to pressure from oyster aquaculture at each location, it is also possible that measurements were made at different time points following the implementation of aquaculture.

Perhaps the most similar study to the one presented here is that of Onorevole et al. (2018), who measured oyster reef sediment $\mathrm{N}$ fluxes along a chronosequence of living shorelines constructed 0,2 , 7 , and 20 yr prior. The authors found no difference in $\mathrm{N}_{2}$ flux from oyster reefs and adjacent sand flat at any age site, although when reefs and adjacent sand flats were pooled, denitrification tended to increase until 7 yr before declining. Oyster density may have played a role in this pattern, with a decrease in the total number of mature oysters with site age $\left(972\right.$ ind. $\mathrm{m}^{-2}$ at the $0 \mathrm{yr}$ site and only 57 ind. $\mathrm{m}^{-2}$ at the $20 \mathrm{yr}$ site), and the distance between sites (maximum $13 \mathrm{~km}$ ) may also have been a factor.

\subsection{What do these results tell us about the role of oyster aquaculture in coastal ecosystems?}

Oyster aquaculture-driven shifts in sediment biogeochemical stable states have important implications for nutrient cycling in coastal systems. Here, we have shown a switch from net $\mathrm{N}$ consumption in bare sediment to net $\mathrm{N}$ release following the installation of oyster aquaculture, with oscillating and highly variable occurrences of $\mathrm{N}_{2}$ and $\mathrm{NH}_{4}{ }^{+}$release and consumption. In coastal systems with excess $\mathrm{N}$ loading from anthropogenic activity, stimulation of net $\mathrm{N}_{2}$ production by oyster aquaculture could serve as an important tool to help reduce the total amount of $\mathrm{N}$ within the system. Indeed, bivalve aquaculturedriven denitrification has previously been suggested as a potential $\mathrm{N}$ management method (Newell et al. 2005), and here we show, for the first time, that not only does oyster aquaculture stimulate sediment denitrification, but that this effect persists over multiple years. However, differences in fluxes across sampling both months and ages of aquaculture, as well as between past studies show that further investigation of the conditions that regulate oyster-mediated sediment denitrification are necessary if it is to be used as a management technique.

In systems with relatively low $\mathrm{N}$ inputs, such as the one investigated here, removal of $\mathrm{N}$ from the system via denitrification could be seen as potentially detrimental to productivity. However, in addition to increased denitrification, we also measured an increase in $\mathrm{N}$ recycling despite no statistical difference from bare sediments due to high variability in fluxes. 
Enhanced recycling of $\mathrm{N}$ from sediments beneath oyster aquaculture does not introduce new $\mathrm{N}$ into the system, but allows for $\mathrm{N}$ atoms to be used for primary production multiple times within the estuary before export to the ocean or removal via denitrification. Thus, oyster aquaculture may have the dual benefit of both removing $\mathrm{N}$ from coastal ecosystems, while also maintaining their productivity.

Finally, as oyster aquaculture drove recycling of mineral $\mathrm{N}$ to the water column, but not $\mathrm{P}$, this could drive $\mathrm{P}$ to become the limiting nutrient for primary production in systems with low P input. In this study, the dissolved inorganic nitrogen (DIN):P flux ratio for bare sediments was $-4.3: 1$, as bare sediments consumed $\mathrm{NH}_{4}{ }^{+}$and released $\mathrm{PO}_{4}{ }^{3-}$, while the DIN:P flux ratio for sediment beneath oyster aquaculture was 26.2:1, possibly driving $\mathrm{P}$ to become a limiting nutrient. The return of $\mathrm{NH}_{4}{ }^{+}$but not $\mathrm{NO}_{\mathrm{x}}$ to the water column may shift phytoplankton communities to functional groups of smaller cell sizes (Glibert et al. 2016). Overall this study highlights the need to characterize the non-linear dynamics of sediment biogeochemical cycling driven by oyster aquaculture, which have important implications for phytoplankton production and composition, and water quality.

Acknowledgements. This study was funded by a Rhode Island Sea Grant award to R.W.F.; N.E.R. was supported by the RI Sea Grant award as well as by a Dean's Fellowship and Teaching Fellowship from the Boston University Biology Department, by the Boston University Marine Program Warren McLeod Research Fellowship, and by a Summer Research Fellowship from the Frederick S. Pardee Center for the Study of the Longer Range Future at Boston University. We are thankful to Jim Arnoux, who provided information about and access to his oyster farm; Dave Beutel from the RI Coastal Resources Management Council for help in site selection and oyster farmer introduction; Suzy Ayvazian, Donn Cobb, and Charley Strobel from the US EPA Atlantic Ecology Division, who helped with field work and provided boat use; Cedric Fichot from Boston University who provided access to an elemental analyzer; and Sarabeth Buckley, Emily Chua, Sarah Donovan, Sarah Foster, Nilotpal Ghosh, Boze Hancock, Gabby Hillyer, Tim Maguire, and Siobhan Sheehan for assistance in the field and lab. Feedback from Pam Templer, Pete Buston, Tony Janetos, and several anonymous reviewers helped to improve this manuscript.

\section{LITERATURE CITED}

Arar EJ, Collins GB (1997) Method 445.0: in vitro determination of chlorophyll $a$ and pheophytin $a$ in marine and freshwater algae by fluorescence. United States Environmental Protection Agency, Office of Research and Development, National Exposure Research Laboratory, Washington, DC
Bates D, Maechler M, Bolker B, Walker S (2015) Fitting linear mixed-effects models using lme4. J Stat Softw 67: $1-48$

Beisner BE, Haydon DT, Cuddington K (2003) Alternative stable states in ecology. Front Ecol Environ 1:376-382

*Benincà E, Huisman J, Heerkloss R, Jöhnk KD and others (2008) Chaos in a long-term experiment with a plankton community. Nature 451:822-825

Berg P, McGlathery KJ (2001) A high-resolution pore water sampler for sandy sediments. Limnol Oceanogr 46: 203-210

* Bolker BM, Brooks ME, Clark CJ, Geange SW, Poulsen JR, Stevens MHH, White JSS (2009) Generalized linear mixed models: a practical guide for ecology and evolution. Trends Ecol Evol 24:127-135

Burgin AJ, Hamilton SK (2007) Have we overemphasized the role of denitrification in aquatic ecosystems? A review of nitrate removal pathways. Front Ecol Environ 5:89-96

Canfield DE, Glazer AN, Falkowski PG (2010) The evolution and future of earth's nitrogen cycle. Science 330:192-196

Cloern JE (1982) Does the benthos control phytoplankton biomass in South San Francisco Bay? Mar Ecol Prog Ser 9:191-202

Colt J (1984) Computation of dissolved gas concentrations in water as functions of temperature, salinity, and pressure. Special Publication 14. American Fisheries Society, Bethesda, MD

Conover W, Johnson ME, Johnson MM (1981) A comparative study of tests for homogeneity of variances, with applications to the outer continental shelf bidding data. Technometrics 23:351-361

Dalsgaard T (ed), Nielsen LP, Brotas V, Viaroli P and others (2000) Protocol handbook for NICE - Nitrogen Cycling in Estuaries: a project under the EU research programme: Marine Science and Technology (MAST III). National Environmental Research Institute, Silkborg

Delignette-Muller ML, Dutang C (2015) fitdistrplus: an R package for fitting distributions. J Stat Softw 64:1-34

* Erler DV, Welsh DT, Bennet WW, Meziane T, Hubas C, Nizzoli D, Ferguson AJP (2017) The impact of suspended oyster farming on nitrogen cycling and nitrous oxide production in a sub-tropical Australian estuary. Estuar Coast Shelf Sci 192:117-127

Fagherazzi S, Mariotti G, Banks AT, Morgan EJ, Fulweiler RW (2014) The relationships among hydrodynamics, sediment distribution, and chlorophyll in a mesotidal estuary. Estuar Coast Shelf Sci 144:54-64

Firestone MK, Davidson EA (1989) Microbiological basis of $\mathrm{NO}$ and $\mathrm{N}_{2} \mathrm{O}$ production and consumption in soil. In: Andreae MO, Schimel DS (eds) Exchange of trace gases between terrestrial ecosystems and the atmosphere. John Wiley \& Sons, New York, NY, p 7-21

* Foster SQ, Fulweiler RW (2014) Spatial and historic variability of benthic nitrogen cycling in an anthropogenically impacted estuary. Front Mar Sci 1:56

Foster SQ, Fulweiler RW (2016) Sediment nitrous oxide fluxes are dominated by uptake in a temperate estuary. Front Mar Sci 3:40

Foster SQ, Fulweiler RW (2019) Estuarine sediments exhibit dynamic and variable biogeochemical responses to hypoxia. J Geophys Res Biogeosci 124:737-758

Fulweiler RW, Heiss EM (2014) (Nearly) a decade of directly measured sediment $\mathrm{N}_{2}$ fluxes: What can Narragansett Bay tell us about the global ocean nitrogen budget? Oceanography 27:184-195 
Fulweiler RW, Nixon SW, Buckley BA, Granger SL (2007) Reversal of the net dinitrogen gas flux in coastal marine sediments. Nature 448:180-182

Fulweiler RW, Nixon SW, Buckley BA (2010) Spatial and temporal variability of benthic oxygen demand and nutrient regeneration in an anthropogenically impacted New England estuary. Estuar Coast 33:1377-1390

Glibert PM, Wilkerson FP, Dugdale RC, Raven JA and others (2016) Pluses and minuses of ammonium and nitrate uptake and assimilation by phytoplankton and implications for productivity and community composition, with emphasis on nitrogen-enriched conditions. Limnol Oceanogr 61:165-197

*Hardison AK, Algar CK, Giblin AE, Rich JJ (2015) Influence of organic carbon and nitrate loading on partitioning between dissimilatory nitrate reduction to ammonium (DNRA) and $\mathrm{N}_{2}$ production. Geochim Cosmochim Acta 164:146-160

*Higgins CB, Tobias C, Piehler MF, Smyth AR, Dame RF, Stephenson K, Brown BL (2013) Effect of aquacultured oyster biodeposition on sediment $\mathrm{N}_{2}$ production in Chesapeake Bay. Mar Ecol Prog Ser 473:7-27

Hougham AL, Moran SB (2007) Water mass ages of coastal ponds estimated using ${ }^{223} \mathrm{Ra}$ and ${ }^{224} \mathrm{Ra}$ as tracers. Mar Chem 105:194-207

Humphries AT, Ayvazian SG, Carey JC, Hancock BT and others (2016) Directly measured denitrification reveals oyster aquaculture and restored oyster reefs remove nitrogen at comparable high rates. Front Mar Sci 3:74

Ingall E, Jahnke R (1994) Evidence for enhanced phosphorus regeneration from marine sediments overlain by oxygen depleted waters. Geochim Cosmochim Acta 58: 2571-2575

Joye S, Hollibaugh J (1995) Influence of sulfide inhibition of nitrification on nitrogen regeneration in sediments. Science 270:623-625

Kana TM, Darkangelo C, Hunt MD, Oldham JB, Bennett GE, Cornwell JC (1994) Membrane inlet mass spectrometer for rapid high-precision determination of $\mathrm{N}_{2}, \mathrm{O}_{2}$, and $\mathrm{Ar}$ in environmental water samples. Anal Chem 66: 4166-4170

Kellogg ML, Cornwell JC, Owens MS, Paynter KT (2013) Denitrification and nutrient assimilation on a restored oyster reef. Mar Ecol Prog Ser 480:1-19

Kraft B, Tegetmeyer H, Sharma R, Klotz M and others (2014) The environmental controls that govern the end product of bacterial nitrate respiration. Science 345:676-679

Kristensen E, Ahmed S, Devol A (1995) Aerobic and anaerobic decomposition of organic matter in marine sediment: Which is fastest? Limnol Oceanogr 40:1430-1437

Kuypers MMM, Marchant HK, Kartal B (2018) The microbial nitrogen-cycling network. Nat Rev Microbiol 16: 263-276

* Lefcheck JS, Orth RJ, Dennison WC, Wilcox DJ and others (2018) Long-term nutrient reductions lead to the unprecedented recovery of a temperate coastal region. Proc Natl Acad Sci USA 115:3658-3662

Lenth R (2018) emmeans: Estimated marginal means, aka least-squares means. R package version 1.2.3. https:// CRAN.r-project.org/web/packages/emmeans/index.html

Lunstrum A, McGlathery K, Smyth A (2018) Oyster (Crassostrea virginica) aquaculture shifts sediment nitrogen processes toward mineralization over denitrification. Estuar Coast 41:1130-1146
Marsland R, Cui W, Goldford J, Sanchez A, Korolev K, Mehta P (2019) Available energy fluxes drive a transition in the diversity, stability, and functional structure of microbial communities. PLOS Comput Biol 15: e1006793

Masterson JP, Sorenson JR, Stone JR, Moran SB, Hougham AL (2007) Hydrogeology and simulated ground-water flow in the Salt Pond region of southern Rhode Island. US Geol Surv Sci Invest Rep 2006-5271

Melillo JM, Frey SD, DeAngelis KM, Werner WJ and others (2017) Long-term pattern and magnitude of soil carbon feedback to the climate system in a warming world. Science 358:101-105

Middelburg JJ, Levin LA (2009) Coastal hypoxia and sediment biogeochemistry. Biogeosciences 6:1273-1293

*Moran SB, Stachelhaus SL, Kelly RP, Brush MJ (2014) Submarine groundwater discharge as a source of dissolved inorganic nitrogen and phosphorus to coastal ponds of southern Rhode Island. Estuaries Coasts 37 : 104-118

Mortazavi B, Ortmann AC, Wang L, Bernard RJ and others (2015) Evaluating the impact of oyster (Crassostrea virginica) gardening on sediment nitrogen cycling in a subtropical estuary. Bull Mar Sci 91:323-341

*Newell RIE, Cornwell JC, Owens MS (2002) Influence of simulated bivalve biodeposition and microphytobenthos on sediment nitrogen dynamics: a laboratory study. Limnol Oceanogr 47:1367-1379

Newell R, Fisher T, Holyoke R, Cornwell J (2005) Influence of eastern oysters on nitrogen and phosphorus regeneration in Chesapeake Bay, USA. In: Dame RF, Olenin S (eds) The comparative roles of suspension-feeders in ecosystems. Springer, Dordrecht, p 93-120

Nixon SW, Kelly JR, Furnas BN, Oviatt CA, Hale SS (1980) Phosphorus regeneration and the metabolism of coastal bottom communities. In: Tenore KR, Coull BC (eds) Marine benthic dynamics. University of South Carolina Press, Columbia, SC, p 219-242

* Nizzoli D, Welsh DT, Fano EA, Viaroli P (2006) Impact of clam and mussel farming on benthic metabolism and nitrogen cycling, with emphasis on nitrate reduction pathways. Mar Ecol Prog Ser 315:151-165

* Onorevole KM, Thompson SP, Piehler MF (2018) Living shorelines enhance nitrogen removal capacity over time. Ecol Eng 120:238-248

* Penn JL, Weber T, Chang BX, Deutsch C (2019) Microbial ecosystem dynamics drive fluctuating nitrogen loss in marine anoxic zones. Proc Natl Acad Sci USA 116: 7220-7225

* Prairie YT (1996) Evaluating the predictive power of regression models. Can J Fish Aquat Sci 53:490-492

Ray NE, Maguire TJ, Al-Haj A, Henning M, Fulweiler RW (2019) Low greenhouse gas emissions from oyster aquaculture. Environ Sci Technol 53:9118-9127

Rowe G, Clifford C, Smith K Jr (1975) Benthic nutrient regeneration and its coupling to primary productivity in coastal waters. Nature 255:215-217

Ryther J, Dunstan W (1971) Nitrogen, phosphorus, and eutrophication in the coastal marine environment. Science 171:1008-1013

Sakamoto Y, Ishiguro M, Kitagawa G (1986) AIC Statistics. Reidel, Dordrecht

Scheffer M, Carpenter S, Foley J, Folke C, Walker B (2001) Catastrophic shifts in ecosystems. Nature 413: 591-596 
Scheffer M, Szabo S, Gragnani A, van Nes EH and others (2003) Floating plant dominance as a stable state. Proc Natl Acad Sci USA 100:4040-4045

Seitzinger SP, Nixon SW (1985) Eutrophication and the rate of denitrification and $\mathrm{N}_{2} \mathrm{O}$ production in coastal marine sediments. Limnol Oceanogr 30:1332-1339

Sørensen J, Tiedje JM, Firestone RB (1980) Inhibition by sulfide of nitric and nitrous oxide reduction by denitrifying Pseudomonas fluorescens. Appl Environ Microbiol 39:105-108

Sundby B, Gobeil C, Silverberg N, Mucci A (1992) The phosphorus cycle in coastal marine sediments. Limnol Oceanogr 37:1129-1145

Tiedje JM (1988) Ecology of denitrification and dissimilatory nitrate reduction to ammonium. In: Zehnder A (ed) Environmental microbiology of anaerobes. John Wiley \& Sons, New York, NY, p 179-244

Tucker J, Giblin AE, Hopkinson CS, Kelsey SW, Howes BL (2014) Response of benthic metabolism and nutrient cycling to reductions in wastewater loading to Boston Harbor, USA. Estuar Coast Shelf Sci 151:54-68

Editorial responsibility: Erik Kristensen,

Odense, Denmark
Turner RE, Qureshi N, Rabalais NN, Dortch Q, Justic D, Shaw RF, Cope J (1998) Fluctuating silicate:nitrate ratios and coastal plankton food webs. Proc Natl Acad Sci USA 95:13048-13051

* Valiela I, Foreman K, Lamontagne M, Hersh D and others (1992) Couplings of watersheds and coastal waters: sources and consequences of nutrient enrichment in Waquoit Bay, Massachusetts. Estuaries 15:443-457

Vieillard A (2017) Impacts of New England oyster aquaculture on sediment nitrogen cycling: implications for nitrogen removal and retention. MSc thesis, University of Connecticut, Storrs, CT

Walker LR, Wardle DA, Bardgett RD, Clarkson BD (2010) The use of chronosequences in studies of ecological succession and soil development. J Ecol 98:725-736

* Weiss RF (1970) The solubility of nitrogen, oxygen and argon in water and seawater. Deep-Sea Res Oceanogr Abstr 17:721-735

Zuur A, Ieno E, Walker N, Saveliev A, Smith G (2009) Mixed effects models and extensions in ecology with R. Springer, New York, NY

Submitted: January 23, 2020; Accepted: May 20, 2020 Proofs received from author(s): July 13, 2020 